\title{
A MECHANISTIC MODELLING APPROACH TO UNDERSTAND 1-MCP \\ INHIBITION OF ETHYLENE ACTION AND QUALITY CHANGES DURING \\ RIPENING OF APPLES
}

Running title: Modelling of apple fruit response to 1-MCP

Authors: Sunny George Gwanpua, ${ }^{\mathrm{a}, \mathrm{c}, *}$, Bert E. Verlinden ${ }^{\mathrm{b}}$, Maarten L.A.T.M. Hertog ${ }^{\mathrm{a}}$, Bart M. Nicolai $^{\mathrm{a}, \mathrm{b}}$, Annemie H. Geeraerd ${ }^{\mathrm{a}}$

${ }^{a}$ Division of Mechatronics, Biostatistics and Sensors (MeBioS), Department of Biosystems (BIOSYST), KU Leuven, W. de Croylaan 42, bus 2428, B-3001 Leuven, Belgium

${ }^{\mathrm{b}}$ Flanders Centre of Postharvest Technology, W. de Croylaan 42, B-3001 Leuven, Belgium

${ }^{c}$ Centre for Postharvest and Refrigeration Research, Massey University, Palmerston North, New Zealand

*Corresponding author. Tel.: +64 6356 9099; E-mail address: s.gwanpua@massey.ac.nz (S.G.

Gwanpua)

\begin{abstract}
BACKGROUND:1-methylcyclopropene (1-MCP) inhibits ripening in climacteric fruit by blocking ethylene receptors, preventing ethylene from binding and eliciting its action. The objective of the current study was to use mathematical models to describe 1-MCP inhibition of apple fruit ripening, and to provide a tool for predicting ethylene production, and two important quality indicators of apple fruit, firmness and background colour.
\end{abstract}

RESULTS: A model consisting of coupled differential equations describing 1-MCP inhibition of apple ripening was developed. Data on ethylene production, expression of ethylene receptors, firmness, and background colour during ripening of untreated and 1-MCP treated apples were

This article has been accepted for publication and undergone full peer review but has not been through the copyediting, typesetting, pagination and proofreading process, which may lead to differences between this version and the Version of Record. Please cite this article as doi: $10.1002 /$ jsfa. 8244

This article is protected by copyright. All rights reserved. 
used to calibrate the model. An overall adjusted $\mathrm{R}^{2}$ of $95 \%$ was obtained. The impact of time from harvest to treatment, and harvest maturity on 1-MCP efficacy was modelled. Different hypotheses on the partial response of 'Jonagold' apple to 1-MCP treatment were tested using the model. The model was validated using an independent dataset.

CONCLUSIONS: Low 1-MCP blocking efficacy was shown to be the most likely cause of partial response for delayed 1-MCP treatment, and 1-MCP treatment of late picked apples. Time from harvest to treatment was a more important factor than maturity for 1-MCP efficacy in 'Jonagold' apples.

Keywords: Malus × domestica; modelling; 1-methylcyclopropene; ethylene; quality

\section{Introduction}

Ethylene is a vital plant hormone that coordinates ripening in climacteric fruit. Increased ethylene production during ripening has been associated with increased gene expression and enzyme activities, such as that of various cell wall hydrolases ${ }^{1-4}$. Exogenous ethylene also promotes ripening related enzymes such as chlorophyllase that is responsible for de-greening of various fruit ${ }^{5-7}$. Other ripening-related physiological changes, such as increased respiration rate and volatile production, have been shown to be tightly regulated by ethylene ${ }^{8-10}$.

To extend postharvest storage, ripening is often delayed by storing fresh fruit and vegetables under conditions that inhibit ethylene biosynthesis. For example, apples are stored at low temperature, often under controlled atmosphere conditions (CA), to keep respiration and ethylene production at low levels ${ }^{11}$. In addition, a common practice, particularly for long term storage of apple, is the application of 1-methylcyclopropene (1-MCP) in storage rooms. 1-MCP is a structural analogue of ethylene that is thought to irreversibly bind to ethylene receptors, preventing the perception and action of ethylene ${ }^{12-16}$. An important aspect of 1-MCP inhibition of ripening is that many fruits tend to recover from 1-MCP treatment ${ }^{17-19}$. This has motivated 
research on the possibility of repeated 1-MCP treatments for more sustained effects ${ }^{20,21}$. Blankenship and Dole ${ }^{14}$ suggested that a partial response in some apple cultivars is related to their ability to regenerate new receptor sites or due to incomplete binding of sites by 1-MCP, where not all receptors are blocked by 1-MCP during treatment. However, such claims remain to be investigated.

Mathematical models offer a useful tool to investigate complex biological mechanisms such as the ethylene signal transduction pathway in apple fruit and its regulation by 1-MCP. They can be used to verify certain hypotheses, and improve our understanding of the biological system. Van de Poel et al. ${ }^{23}$ developed a transcriptomic-based kinetic model for ethylene biosynthesis in ripening tomato fruit, and used it to evaluate different hypotheses regarding the regulation of ethylene biosynthesis. Additionally, mathematical modelling has been used extensively to predict how storage conditions (temperature and atmosphere) influence postharvest quality evolution ${ }^{24-29}$. To the best of our knowledge, only two attempts have been made to model the impact of 1-MCP on postharvest quality changes. Ochoa-Ascencio et al. ${ }^{30}$ modelled 1-MCP regulation of softening in avocado using a discrete on/off approach in which autocatalytic production of active enzyme was temporarily switched off in 1-MCP treated fruit, and switched on after the 1-MCP effect diminished. While the model was able to describe 'Hass' avocado softening, it did not explain the kinetics involved in the subsequent rise in ethylene production and quality deterioration observed in 1-MCP treated fruits following prolonged shelf life exposure. The other study by Cocci et al. ${ }^{31}$ used a simple polynomial function to model the effectiveness of 1-MCP treatment, as a function of applied dose, maturity at harvest, storage time and CA storage in apple fruit.

In the current study, we aimed to develop a more complete dynamic model to predict how 1$\mathrm{MCP}$ inhibits ethylene perception and response, and how regeneration of new receptor sites might contribute to restore ethylene perception, autocatalytic ethylene production, and ripeningrelated quality changes (softening and loss in skin greenness) in 'Jonagold' apple. In developing 
this model, parameters related to the ethylene signal transduction were estimated using published data of ethylene production and transcript levels of receptor genes during ripening of 'Golden Delicious' apples, with and without 1-MCP treatment ${ }^{32}$. New experimental data on ethylene production, firmness and skin background colour during ripening of 'Jonagold' apples, with and without 1-MCP treatment, were collected for estimating parameters relating the ethylene response to quality changes. Practical implications of the model will be discussed, and different hypothesis on the partial response of 1-MCP application will be investigated.

\section{Material and Methods}

\section{Plant Material}

'Jonagold' (Malus $\times$ domestica Borkh.) apple fruit were harvested, both at commercial maturity and two weeks later. Commercial maturity was determined by the Flanders Centre of Postharvest (VCBT), using a combination of firmness, starch pattern index, soluble solids content, skin colour, and respiration rates ${ }^{33}$.

1-MCP (SmartFresh ${ }^{\mathrm{TM}}$, AgroFresh Inc. Spring House, PA, USA) application was carried out at $4{ }^{\circ} \mathrm{C}$ following the manufacturer's guidelines, exposing the fruit to 1 -MCP dosage of $0.625 \mathrm{mg}$ $\mathrm{L}^{-1}$ total volume, in airtight containers for $24 \mathrm{~h}$. The optimally harvested fruit were divided into four batches. One batch was immediately stored at $1{ }^{\circ} \mathrm{C}$ under $\mathrm{CA}$ conditions $(1 \mathrm{kPa} \mathrm{O}$ and 3 $\mathrm{kPa} \mathrm{CO}_{2}$ ), the second and third batches were precooled and treated the following day with 1MCP, before storing at $1{ }^{\circ} \mathrm{C}$ and $4^{\circ} \mathrm{C}$, respectively, under CA. The fourth batch of the optimally harvested fruit underwent a delayed 1-MCP and CA treatment: it was kept for two weeks at 1 ${ }^{\circ} \mathrm{C}$ in air before 1-MCP treatment was applied, after which the fruit was stored under $\mathrm{CA}$. All late harvested fruit (batch 5) were treated with 1-MCP immediately after cooling, and were subsequently stored at $1{ }^{\circ} \mathrm{C}$ under $\mathrm{CA}$ conditions. The different treatments aimed to induce different responses to 1-MCP application. At the end of 6 months storage, the apples were 
placed under ambient shelf life conditions $\left(18{ }^{\circ} \mathrm{C}\right.$ in air) for seven weeks, during which fruit were sampled every week for measurements of ethylene production, firmness, and background colour. Batch 1, 2, 3 and 5 were used for model calibration, while batch 4 was used for model validation.

\section{Firmness and background colour measurements}

Flesh firmness was measured using an LRX Universal Testing Machine (Lloyd Instruments, UK), equipped with a load cell of $500 \mathrm{~N}$. A self-cutting cylindrical plunger with a surface of 1 $\mathrm{cm}^{2}$, was attached to the load cell and allowed to move at a constant speed of $8 \mathrm{~mm} \mathrm{~s}^{-1}$ towards the fruit. The firmness was taken as the maximum force $(\mathrm{N})$ needed for the plunger to penetrate the fruit to a depth of $8 \mathrm{~mm}$. Two measurements were taken on the equator, one at the blush side and one at the green side, and averaged. Skin background colour was measured as the $a^{*}$ value of the CIE colour system using a hand-held spectrophotometer (Model CM-2600D, Minolta, Kontich, Belgium) calibrated to a white tile. For each sampling time, the firmness of 20 fruit was measured, while the evolution of the background colour for 30 fruit from each batch was followed.

\section{Measurement of ethylene production}

Ethylene production was measured following the protocol of Bulens et al. (2011). An apple was initially enclosed in a jar of $1.1 \mathrm{~L}$ and flushed for 1 hour with humidified air at $18{ }^{\circ} \mathrm{C}$. The inlet and outlet of the jars were then closed and kept at $18{ }^{\circ} \mathrm{C}$ for $4 \mathrm{~h}$ to allow for sufficient ethylene production. $3 \mathrm{~mL}$ gas samples were withdrawn from the jars and analysed by injecting into a CompactGC (Interscience, Louvain-la-Neuve, Belgium) gas chromatograph. Calibration was done by ethylene standards ranging from $50 \mu \mathrm{g} \mathrm{L}^{-1}$ to $50 \mathrm{mg} \mathrm{L}^{-1}$. For each sampling time, the ethylene production of four individual fruit was measured.

\section{Expression of ethylene receptor genes}

This article is protected by copyright. All rights reserved. 
Data on the expression of ethylene receptor genes during ripening of 'Golden Delicious' apples, in fruit treated with and without 1-MCP, reported by Yang et al. (2013), was used in this study. The fruit were harvested 1 week before commercial maturity, and allowed to ripen in air at $20{ }^{\circ} \mathrm{C}$, following treatment. $1-\mathrm{MCP}$ treatment was done by placing the fruit in $1 \mu \mathrm{L} \mathrm{L}^{-1}$ of 1 MCP (EthylBloc, 0.14\%, Rohm and Haas Company, Philadelphia, PA) in sealed containers for $12 \mathrm{~h}$ at $20^{\circ} \mathrm{C}$, while the control group was held at $20^{\circ} \mathrm{C}$ for $12 \mathrm{~h}$ without any 1 -MCP treatment. For both the 1-MCP treated and control fruit, the ethylene production was measured at intervals during ripening, while tissue samples were also collected, frozen and stored at $-85{ }^{\circ} \mathrm{C}$ for later quantification of the expression levels of receptor genes by real-time qPCR, as detailed in Yang et al. $^{32}$. The gene expression data of other signal transduction molecules reported in that study were not used, since the objective of the current study was to model how regeneration of receptors was responsible for partial responses of apple to 1-MCP treatment, rather than to model the complete ethylene signal transduction pathway. Also, we assumed that the different isoforms of the receptors have similar ethylene binding ${ }^{35}$, hence overall receptor abundance was taken as the sum of the expression of all five ETR genes (ETR1, ETR2, ETR5, ERS1, and ERS2) reported in Yang et al. ${ }^{32}$. The ethylene production and receptor genes expression data were digitized from the plots in Yang et al. ${ }^{32}$. The work by Yang et al. ${ }^{32}$ provided the most suitable data to complement our current study, as, to the best of our knowledge, it is the only study reporting the evolution of receptor genes and ethylene production during ripening in an apple cultivar with ripening physiology closed to that of 'Jonagold' apples.

\section{Model development}

\section{Theoretical basis of ethylene perception and 1-MCP inhibition}

A schematic representation of the ethylene perception and response pathways is shown in Fig. 1. In the absence of ethylene, ethylene receptors present in the ER membrane is phosphorylated 
and in an activated form, $\mathrm{ETR}^{+},{ }^{36}$. In this form, $\mathrm{ETR}^{+}$interacts with the constitutive triple response 1 (CTR1), a key regulator of the ethylene response ${ }^{37}$. This interaction with $\mathrm{ETR}^{+}$ maintains CTR1 in its activated form, $\mathrm{CTR} 1^{+}$. $\mathrm{CTR} 1^{+}$inactivates the ethylene response by phosphorylating EIN2, a positive regulator of the ethylene response ${ }^{38}$. Ethylene, when present, binds to $\mathrm{ETR}_{\text {free }}^{+}$, altering the phosphorylation state of the receptor, referred to as receptor inactivation $\left(\mathrm{ETR}^{-}\right)$in Fig 1. Conversely, 1-MCP binds to receptors without altering the phosphorylation state ${ }^{36}$. Therefore, both the free ethylene receptors $\left(\mathrm{ETR}_{\text {free }}^{+}\right)$and ethylene receptors bound to $1-\mathrm{MCP}\left(\mathrm{ETR}_{1-\mathrm{MCP}}^{+}\right)$exist in the activated form, maintaining $\mathrm{CTR} 1$ in its activated form, and repressing the ethylene response.

Binding of ethylene to its receptor also triggers the degradation of the receptor ${ }^{39,40}$, but this was not included in the scheme as we were only interested in how receptor inactivation influences ethylene responses, and not in the fate of the inactivated receptors. Inactivation of the receptors switches on the ethylene signal transduction, ultimately resulting to the production of ethylene response factors (ERF) in the nucleus. The complete details of the ethylene signal transduction were not considered in the model, but it was assumed that the rate at which the ERF is produced is proportional to the rate at which the receptors are being inactivated as a result of binding with ethylene. ERF regulates the transition of the fruit from the pre-climacteric state, $f_{\text {clim }} \approx 0$, to the climacteric maximum, $f_{\text {clim }} \approx 1$. The rate of autocatalytic ethylene production was assumed to be proportional to the rate at which the climacteric state of the fruit is changing, such that it is highest during the switch from the pre-climacteric to the climacteric state, and declines to zero once the climacteric maximum is reached (as the fruit enters into senescence). As examples of ethylene-regulated ripening-related quality deterioration, it was assumed that ERF regulates the synthesis of pectin modifying and chlorophyll degrading enzymes, which 
catalyse the dissolution of cell wall pectin and the breakdown of skin chlorophyll pigments, respectively.

1-MCP was assumed to bind irreversibly to ethylene receptors ${ }^{15}$, and it was also assumed that any partial response was due to regeneration of new receptors or due to incomplete blocking of receptors ${ }^{14}$. The expression of receptors genes has been shown to be dependent on developmental stage and external stimuli ${ }^{41}$. In this model, it was assumed that the rate of expression of the ethylene receptor genes was regulated by the rate at which the climacteric state of the fruit, $f_{\text {clim }}$, was changing.

Both the proteins and mRNAs were assumed to be subjected to turnover due to degradation. The scheme in Figure 1 was translated into a set of differential equations, as detailed below.

\section{Model equations}

\section{Ethylene perception and response}

The rate of inactivation of the ethylene receptor was assumed to be proportional to the amount of internal ethylene and the free receptors (Eq. (1)).

$\frac{d\left[\mathrm{ETR}^{-}\right]}{d t}=k_{\text {inact, ETR }}\left[\mathrm{C}_{2} \mathrm{H}_{4}\right]\left[\mathrm{ETR}_{\text {free }}^{+}\right]$

with $\left[\mathrm{ETR}^{-}\right](t=0)=\left[\mathrm{ETR}^{-}\right]_{0}$

where $\left[\mathrm{ETR}^{-}\right]$and $\left[\mathrm{ETR}_{\text {free }}^{+}\right]$are the concentration of inactivated and free receptors, respectively, $k_{\text {inact,ETR }}$ is the rate constant for the inactivation of the receptor, $\left[\mathrm{ETR}^{-}\right]_{0}$ is the initial concentration of inactivated receptors and $t$ is time.

This article is protected by copyright. All rights reserved. 
Concentration changes of free ethylene receptor, $\mathrm{ETR}_{\text {free }}^{+}$, were assumed to be proportional to the synthesis of new receptor proteins, and inactivation of receptors by ethylene binding (Eq. (2)).

$$
\begin{aligned}
& \frac{d\left[\mathrm{ETR}_{\text {free }}^{+}\right]}{d t}=k_{t, \mathrm{ETR}}\left[\mathrm{mRNA}_{\mathrm{ETR}}\right]-k_{\text {inact,ETR }}\left[\mathrm{C}_{2} \mathrm{H}_{4}\right]\left[\mathrm{ETR}_{\text {free }}^{+}\right] \\
& \text {with }\left[\mathrm{ETR}_{\text {free }}^{+}\right](t=0)=\left(1-\chi_{\mathrm{ETR}_{\text {block }}}\right)\left[\mathrm{ETR}^{+}\right]_{0}
\end{aligned}
$$

where $k_{t, \mathrm{ETR}}$ is the rate constant for the synthesis of new receptor proteins, $\left[\mathrm{mRNA}_{\mathrm{ETR}}\right]$ is the mRNA abundance of the receptor mRNA, $\left[\mathrm{ETR}^{+}\right]_{0}$ is the concentration of activated receptors (both free and 1-MCP bound) at time zero (at the beginning of CA storage), and $\chi_{\mathrm{ETR}_{\text {block }}}$ is the proportion of activated receptors bound to 1-MCP (following 1-MCP treatment). For non-1MCP treated fruit, $\chi_{\mathrm{ETR}_{\text {block }}}=0$.

The rate of expression of the receptor gene was modelled by the following equation:

$$
\begin{aligned}
& \frac{d\left[\mathrm{mRNA}_{\mathrm{ETR}}\right]}{d t}=k_{\mathrm{mRNA}_{\mathrm{ETR}}} \frac{d f_{\text {clim }}}{d t}-k_{\mathrm{deg}, \mathrm{mRNA}_{\mathrm{ETR}}}\left[\mathrm{mRNA}_{\mathrm{ETR}}\right] \\
& \text { with }\left[\mathrm{mRNA}_{\mathrm{ETR}}\right](t=0)=\left[\mathrm{mRNA}_{\mathrm{ETR}}\right]_{0}
\end{aligned}
$$

where $k_{\mathrm{mRNA}_{\mathrm{ETR}}}$ and $k_{\mathrm{deg}, \mathrm{MRNA}_{\mathrm{ETR}}}$ are the rate constants for the expression of the receptor gene and degradation of the receptor gene transcripts, respectively. Here we assumed that during the transition from the pre-climacteric minimum to the climacteric maximum, the fruit metabolism (and hence rate of expression of receptor genes) is at its maximum (See Supplementary Fig S1 for behaviour of $f_{\text {clim }}$ and $\frac{d f_{\text {clim }}}{d t}$ ). As the fruit approaches the climacteric maximum, the rate of expression of the receptor genes starts declining and reaches zero at the climacteric maximum, 
as the fruit enters into senescence. The residual receptor mRNA abundance starts declining following the degradation term in Eq. (3).

As earlier explained, the details of the ethylene signal transduction pathway, including the dephosphorylation of the EIN2 and the activation of EIN3/EIL1 transcription factors, were not included in the model. Rather, since the inactivation of receptors by ethylene binding ultimately results to the synthesis of ERF, the rate of production of the ERF protein was assumed to be directly proportional to the rate of inactivation of the receptors (Eq. (4)).

$\frac{d[\mathrm{ERF}]}{d t}=k_{\mathrm{ERF}} \frac{d\left[\mathrm{ETR}^{-}\right]}{d t}-k_{\mathrm{deg}, \mathrm{ERF}}[\mathrm{ERF}]$ with $[\mathrm{ERF}](t=0)=[\mathrm{ERF}]_{0}$

where $[E R F]$ is the concentration of the ERF protein, $k_{\mathrm{ERF}}$ and $k_{\mathrm{deg}, \mathrm{ERF}}$ are the rate constants for the synthesis and turnover of the ERF proteins.

An implication of Eq. (4) is that a high, but constant, level of $\mathrm{ETR}^{-}$would not induce formation of ERFs, and hence ethylene-regulated processes would start declining. Theoretically, a buildup to a high and constant concentration of inactivated receptors does not happen, as degradation of the receptor is triggered following ethylene binding ${ }^{39}$.

\subsubsection{Change in climacteric state}

The transition from the pre-climacteric state to the post-climacteric state was modelled by a logistic function, with the rate of the switch being regulated by ERF through Michaelis-Menten type kinetics as shown in Eq. (5).

$\frac{d f_{\text {clim }}}{d t}=k_{\text {clim }} \frac{[\mathrm{ERF}]}{\mathrm{K}_{\mathrm{m}, \mathrm{ERF}}+[\mathrm{ERF}]} f_{\mathrm{clim}}\left(1-f_{\mathrm{clim}}\right)$ with $f_{\mathrm{clim}}(t=0)=f_{\mathrm{clim}, 0}$

where $k_{\text {clim }}$ is the rate of transition from pre-climacteric to the climacteric maximum, and $\mathrm{K}_{\mathrm{m}, \mathrm{ERF}}$ is the Michaelis-Menten constant for the regulation of the climacteric switch by ERF. 


\subsubsection{Ethylene production}

The ethylene production was modelled by Michaelis-Menten kinetics, similar to the approach used by Gwanpua et al. ${ }^{42}$.

$$
\begin{aligned}
& \frac{d\left[\mathrm{C}_{2} \mathrm{H}_{4}\right]}{d t}=\frac{d f_{\text {clim }}}{d t} V_{\mathrm{m}, \mathrm{C}_{2} \mathrm{H}_{4}} \frac{P_{\mathrm{O}_{2}}}{K_{\mathrm{m}, \mathrm{O}_{2}, \mathrm{C}_{2} \mathrm{H}_{4}}+P_{\mathrm{O}_{2}}\left(1+\frac{P_{\mathrm{CO}_{2}}}{K_{m u, \mathrm{CO}_{2}, \mathrm{C}_{2} \mathrm{H}_{4}}}\right)}-k_{\mathrm{diff}}\left[\mathrm{C}_{2} \mathrm{H}_{4}\right] \\
& \text { with }\left[\mathrm{C}_{2} \mathrm{H}_{4}\right](t=0)=\left[\mathrm{C}_{2} \mathrm{H}_{4}\right]_{0}
\end{aligned}
$$

where $\left[\mathrm{C}_{2} \mathrm{H}_{4}\right]$ is the internal ethylene concentration (IEC); $V_{\mathrm{m}, \mathrm{C}_{2} \mathrm{H}_{4}}$ is the maximum rate of ethylene production; $K_{\mathrm{m}, \mathrm{O}_{2}, \mathrm{C}_{2} \mathrm{H}_{4}}$ and $K_{m u, \mathrm{CO}_{2}, \mathrm{C}_{2} \mathrm{H}_{4}}$ are the Michaelis-Menten constants for ethylene production and uncompetitive inhibition of ethylene production by carbon dioxide, respectively; $P_{\mathrm{O}_{2}}(\mathrm{kPa})$ and $P_{\mathrm{CO}_{2}}(\mathrm{kPa})$ are the external partial pressure of oxygen and carbon dioxide respectively; $k_{\text {diff }}$ is the rate of ethylene diffusing from the apple tissue to its surrounding. For the latter it is assumed that the external ethylene concentration was negligible, compared to the IEC $\left[\mathrm{C}_{2} \mathrm{H}_{4}\right]$.

\subsubsection{Softening and chlorophyll breakdown}

It was assumed that the rate of synthesis of pectin modifying enzymes $\left(\mathrm{E}_{\text {Pect }}\right)$ and chlorophyll degrading enzymes $\left(\mathrm{E}_{\mathrm{Chl}}\right)$ were proportional to the amount of ERF and reciprocal to the rate of enzyme turnover (Eqs. (7) and (8)).

$$
\begin{aligned}
& \frac{d\left[\mathrm{E}_{\text {Pect }}\right]}{d t}=k_{\mathrm{E}_{\text {Pect }}}[\mathrm{ERF}]-k_{\text {deg, }, \mathrm{E}_{\text {Pect }}}\left[\mathrm{E}_{\text {Pect }}\right] \text { with }\left[\mathrm{E}_{\text {Pect }}\right](t=0)=\left[\mathrm{E}_{\text {Pect }}\right]_{0} \\
& \frac{d\left[\mathrm{E}_{\mathrm{Chl}}\right]}{d t}=k_{\mathrm{E}_{\mathrm{Chl}}}[\mathrm{ERF}]-k_{\mathrm{deg}, \mathrm{E}_{\mathrm{Chl}}}\left[\mathrm{E}_{\mathrm{Chl}}\right] \text { with }\left[\mathrm{E}_{\mathrm{Chl}}\right](t=0)=\left[\mathrm{E}_{\mathrm{Chl}}\right]_{0}
\end{aligned}
$$


where $k_{\mathrm{E}_{\mathrm{Pect}}}$ and $k_{\mathrm{deg}, \mathrm{E}_{\mathrm{Pect}}}$ are the rate constants for the synthesis and degradation of $\mathrm{E}_{\text {Pect }}$, respectively; $k_{\mathrm{E}_{\mathrm{Chl}}}$ and $k_{\mathrm{deg}, \mathrm{E}_{\mathrm{Chl}}}$ are the rate constants for the synthesis and degradation of $\mathrm{E}_{\mathrm{Chl}}$. $\mathrm{E}_{\text {Pect }}$ and $\mathrm{E}_{\mathrm{Chl}}$ were assumed to drive modifications in cell wall during softening, and chlorophyll degradation, respectively, by the following equations.

$$
\begin{aligned}
& \frac{d[\text { Pect }]}{d t}=-k_{\text {Pect }}\left[\text { Pect }_{\text {intact }}\right]\left[\mathrm{E}_{\text {Pect }}\right] \text { with }\left[\text { Pect }_{\text {intact }}\right](t=0)=\left[\text { Pect }_{\text {intact }}\right]_{0} \\
& \frac{d[\mathrm{Chl}]}{d t}=-k_{\mathrm{Chl}}[\mathrm{Chl}]\left[\mathrm{E}_{\mathrm{Chl}}\right] \text { with }[\mathrm{Chl}](t=0)=[\mathrm{Chl}]_{0}
\end{aligned}
$$

where $k_{\mathrm{Pect}}$ and $k_{\mathrm{Chl}}$ are the rate constants for breakdown of cell wall pectin polysaccharide and the chlorophyll degradation, respectively; Pect is the amount of unhydrolysed pectin, and Chl is the chlorophyll content. It should be noted that Eq. (9) is a rather simplified representation of pectin breakdown, which involves several enzymes working in a concerted manner on different part of the pectin molecules ${ }^{2,43-45}$. Similarly, the actual chlorophyll degradation reactions are much more complex than was modelled in Eq. (10) ${ }^{46}$. However, we believe the current simplification is sufficient to explain the effect of ethylene response on softening and loss in skin greenness.

Temperature dependencies of all rate constants were modelled according to the Arrhenius equation.

$$
k_{i}=k_{i, \text { ref }} \exp \left(\frac{E_{a, i}}{R}\left(\frac{1}{T_{\text {ref }}}-\frac{1}{T}\right)\right)
$$

where $k_{i}$ is a rate constant, having $k_{i \text {,ref }}$ as a reference value at a certain reference temperature $T_{\text {ref }}(293.15 \mathrm{~K}) ; E_{a, i}\left(\mathrm{~J} \mathrm{~mol}^{-1}\right)$ is the activation energy for the respective reactions; $R(8.3144 \mathrm{~J}$ $\left.\mathrm{mol}^{-1} \mathrm{~K}^{-1}\right)$ is the universal gas constant, and $T(\mathrm{~K})$ is the temperature. 


\section{Output relations}

Firmness and background colour were used to estimate the extent of pectin modifications and chlorophyll degradations, respectively, during ripening. Although the relation between cell wall pectin and texture (in this case firmness) is a very complex one, depending on the overall pectin structure (such as size of pectin chains, pectin degree of methyl esterification, amount and type of pectin side chain neutral sugars, and pectin solubility ${ }^{2,44,47,48}$ ), a direct relation was assumed between the amount of unhydrolysed pectin, as modelled by Pect $_{\text {intact }}$, and firmness (Eq. (12)).

$F=F_{c}+\gamma\left[\right.$ Pect $\left._{\text {intact }}\right]$

where $F_{c}$ is a fixed part of firmness not affected by pectin modifications, and $\gamma$ is a conversion factor between intact pectin and firmness. Since no changes in cell wall pectin was quantified, $\gamma$ was kept fixed at $1 \mathrm{~N} \mathrm{mmol}^{-1} \mathrm{~m}^{3}$. In a recent publication a relationship was established between apple skin background colour ( $\left.a^{*}\right)$ and chlorophyll content ${ }^{42}$ :

$a^{*}=a^{*}{ }_{\mathrm{C}}-\alpha[\mathrm{Chl}]^{\beta}$

where $a^{*}{ }_{\mathrm{C}}$ is a fixed part of the background colour, related to the yellow pigments that are present in the skin but are not subjected to significant postharvest degradation ${ }^{49}, \alpha\left(13.6 \mathrm{nmol}^{-}\right.$ $\left.{ }^{1} \mathrm{~cm}^{3}\right)$ and $\beta(0.38)$ are constants with their values as determined by ${ }^{42}$.

The ethylene emission, $\phi_{\mathrm{C}_{2} \mathrm{H}_{4}}$, is related to the IEC by the following expression:

$\phi_{\mathrm{C}_{2} \mathrm{H}_{4}}=\frac{k_{\text {diff }}\left[\mathrm{C}_{2} \mathrm{H}_{4}\right]}{\eta}$

Where $\eta$ is a factor used to convert ethylene emission in $\mathrm{nmol} \mathrm{kg}^{-1} \mathrm{~s}^{-1}$ to $\mathrm{mmol} \mathrm{m} \mathrm{d}^{-1}$, taking into account the average density of the fruit.

This article is protected by copyright. All rights reserved. 


\section{Model calibration}

\subsubsection{Calibration dataset}

The model parameters of the ethylene perception and response, change in climacteric state and ethylene production (Eqs. (1) - (6)) were estimated using data of ethylene production and expression of ETR genes (ETR1, ETR2, ETR5, ERS1, and ERS2) during ripening of 1-MCP treated and untreated 'Golden Delicious' (Malus $\times$ domestica Borkh.) apples. It was assumed that $95 \%$ of the active receptors was bound by $1-\mathrm{MCP}$, following treatment. Therefore, $\chi_{\mathrm{ETR}_{\text {block }}, 0}$ was set to 0 for the non-treated fruit, and 0.95 for the treated fruit harvested at optimal harvest time. Also, it was assumed that at harvest only $5 \%$ of the total receptors were in the inactivated form, because of the very low amount of ethylene production. Therefore, by setting $\left[\mathrm{ETR}^{-}\right]_{0}$ to a normalized value of $1,\left[\mathrm{ETR}^{+}\right]_{0}$ was kept at 19 . Also, $[\mathrm{ERF}]_{0}$ was given a normalised value of 1 . The Michaelis-Menten constants for $\mathrm{O}_{2}$ and $\mathrm{CO}_{2}$ inhibition of ethylene production reported in Gwanpua et al. ${ }^{50}$ for 'Jonagold' apples were used ( $K_{\mathrm{m}, \mathrm{O}_{2}, \mathrm{C}_{2} \mathrm{H}_{4}}=4.44 \mathrm{kPa}$ and $\left.K_{\mathrm{mu}, \mathrm{CO}_{2}, \mathrm{C}_{2} \mathrm{H}_{4}}=0.76 \mathrm{kPa}\right) . k_{\mathrm{deg}, \mathrm{mRNA}_{\mathrm{ETR}}}$ and $k_{\mathrm{deg}, \mathrm{ERF}}$ were kept fixed at some arbitrary values, as the data did not provide sufficient information about the degradation terms. Moreover, as $k_{\text {inact,ETR }}$ and $k_{t, \text { ETR }}$ are coupled parameters, based on Eq. (2), trying to estimate both without data on protein abundance of the receptors may result into an over-parameterised model. Therefore, one of these parameters, $k_{t, \text { ETR }}$, was fixed at 0.01 . Since the 'Golden Delicious' apples were harvested at pre-climacteric state, $f_{\text {clim }, 0}$ was fixed at a very low value of 0.01 . The rest of the model parameters were estimated by fitting the measured data from Yang et al. ${ }^{32}$ on ethylene production and ethylene receptor genes expression to the model ODEs.

The data obtained with our experiments were used for estimating the model parameters relating ethylene response to softening and chlorophyll breakdown. Separate values of $\mathrm{F}_{0}, a_{0}^{*}, f_{\text {clim, } 0}$

This article is protected by copyright. All rights reserved. 
and $\left[\mathrm{mRNA}_{\mathrm{ETR}}\right]_{0}$ were estimated for the optimal picked, delayed 1-MCP treatment, and late picked fruit, as these parameters (namely, initial firmness, background colour, climacteric state, and expression of receptor genes) are all related to the fruit maturity. As explained earlier, the $\chi_{\mathrm{ETR}_{\text {block }}, 0}$ value of the control fruit was set at 0 , while it was set at 0.95 for the optimal 1-MCP application. Separate values were then estimated for the delayed 1-MCP and the 1-MCP application of late-picked apples, since the proportion of activated receptors bound to 1-MCP depends on the IEC relative to the amount of receptors, and the different batches of fruit probably had different IEC during the 1-MCP treatment. $F_{\mathrm{c}}$ and $k_{\text {diff }}$ were obtained from Gwanpua et al. ${ }^{50}$ and Gwanpua et al. $^{50}$, respectively. Finally, since we did not have data on chlorophyll degradation enzymes or pectinases, $k_{\mathrm{E}_{\mathrm{Chl}}}$ and $k_{\mathrm{E}_{\mathrm{Pect}}}$ were set at fixed values, following some initial optimisation.

\subsubsection{Parameter optimisation}

The ordinary differential equations (ODEs) were solved numerically using the ode45 solver in MATLAB 2014a (The MathWorks Inc., Natick, MA, USA). As the output variables differ considerable in magnitude, a normal transformation was applied to each of the dependent variables before model parameters were estimated using the weighted least-squares method.

Model implementation and parameter optimisation was done using OptiPa, a MATLAB graphical user interface for kinetic modelling ${ }^{51}$. The developed code is provided as a supplementary material (Supporting Notes S1).

\section{Results and discussion}

\section{Model calibration}

It was observed from the data that the peak value of ethylene production was much higher for the control fruit than for the 1-MCP treated fruit (Figure 2). It is likely that because of the slow 
rise in climacteric state in $1-\mathrm{MCP}$ treated apples, the climacteric maximum of ethylene production was reduced as well. Therefore, separate values for the $V_{\mathrm{m}, \mathrm{C}_{2} \mathrm{H}_{4}}$ were estimated for the control and the treated fruit (Table 1). $\mathrm{K}_{\mathrm{m}, \mathrm{ERF}}$ was kept fixed as the standard error of the estimate was always very large. The model could explain $87 \%$ of the ethylene production and ETR expression data for the untreated and 1-MCP treated 'Golden Delicious' apples.

\section{Ethylene production and quality evolution}

A second model calibration was done for the complete model, including the part related to firmness decay and loss in skin background colour, using our experimental data. The model parameters estimates related to the ETR expression and the ethylene signal transduction were kept fixed at the values estimated from the data of Yang et al..$^{32}$, as described in the previous paragraph. It should be noted that both 'Golden Delicious' and 'Jonagold' apples have been shown to have comparable 1-MCP adsorption rate constant ${ }^{52}$. The study by Yang et al. ${ }^{32}$ did not include any storage, while in the current study the fruit were stored in CA before being allowed to ripen under ambient shelf life conditions. Therefore, the model was extended to include the effect of temperature, using the Arrhenius equation. A reference temperature of $20{ }^{\circ} \mathrm{C}$ was chosen, since the study by Yang et al. ${ }^{32}$ was carried out at this temperature. The activation energies related to ethylene production and quality degradation were obtained previously ${ }^{42,50}$, while those related to ethylene perception and response were kept at some plausible value following some preliminary optimisation based on the associated rate constants at $20{ }^{\circ} \mathrm{C}$ obtained in the previous model fitting (Table 2). $\left[\mathrm{E}_{\mathrm{pect}}\right]_{0}$ and $\left[\mathrm{E}_{\mathrm{Chl}}\right]_{0}$ were set at a nominalised value of 1 , while the remainder of the model parameters were estimated by calibrating the model ODEs using our data. Moreover, as indicated higher, 1-MCP treatment affects the climacteric peak value of ethylene production. In principle, different 1-MCP treatments may result in different ethylene production rates at the climacteric maximum, but to reduce the 
number of parameters, a common $V_{\mathrm{m}_{\mathrm{C}} \mathrm{H}_{4}}$ was estimated for all 1-MCP treated fruit, while a separate value was estimated for the control fruit. We did not find enough support for a degradation term $k_{\mathrm{deg}, \mathrm{E}_{\mathrm{Chl}}}$ and $k_{\mathrm{deg}, \mathrm{E}_{\mathrm{Pect}}}$, and therefore the values were set to zero. The model parameter estimates are shown in Table 3, while the model simulations, plotted against the measured data for the evolution of the ethylene production, firmness, and skin background colour, are shown in Figure 3. Time zero was assumed to be the time at the start of CA. Only predictions and measurements at the end of storage and during ripening under shelf life conditions are shown in Figure 3. The model could explain $98 \%$ of the measured firmness, background colour and ethylene production data for all treatments. From the data of ethylene production and quality evolution, the most potent 1-MCP effect was obtained for the optimally harvested 'Jonagold' apples that were treated with 1-MCP immediately after cooling. The delayed 1-MCP application was least effective in controlling ethylene production with two weeks at $20{ }^{\circ} \mathrm{C}$, with fruit able to regain climacteric rise in ethylene production within two weeks under ambient shelf life conditions. Fruit that were late picked, but immediately treated with 1-MCP, had an intermediate response. Based on the firmness data, the delayed 1-MCP treated fruit softened more than the control fruit during storage, probably due to higher IECs resulting from delayed application of $1-\mathrm{MCP}$ and associated late application of $\mathrm{CA}^{13}$. However, when the fruit were removed from storage and allowed to ripen under shelf life conditions, the firmness of the control fruit rapidly diminished to values lower than for all other treatments. The trend was a little different for the skin background colour, as the late picked fruit had the highest $a^{*}$ - value at the end of CA storage. This could be due to the fact that at harvest the $a^{*}$ - value for skin background for the late harvested apples was higher than those of the optimal harvested apples.

The importance of time from harvest to $1-\mathrm{MCP}$ treatment on quality deterioration in apples is variable, depending on the cultivar and other storage treatment ${ }^{53}$. Other studies have shown that delays in 1-MCP application may or may not influence efficacy of the treatment. For example, 
Amarante et al. ${ }^{54}$ showed that a delay of up to 20 days before application of 1-MCP did not have a significant influence on the firmness of 'Fuji' apples after 9 months storage in air. However, their assessment was limited to the firmness at the end of storage, and after 7 days at $23{ }^{\circ} \mathrm{C}$. Contrarily, Watkins and Nock ${ }^{13}$ showed that delaying CA application by two weeks resulted in a significant increase in the IECs, and significantly influenced the effectiveness of 1-MCP treatment, particularly in fruit with low IECs at harvest. They suggested that rapid treatment of apples with 1-MCP after harvest could compensate for delay in CA application. Our findings demonstrate that 1-MCP treatment done after a considerable delay in CA application will result only into partial suppression of ripening in 'Jonagold' apples.

\section{Low 1-MCP blocking efficacy chiefly responsible for poor response to delayed 1-MCP}

\section{treatment}

A number of hypotheses have been postulated to explain why the time from harvest to treatment and the maturity at harvest influence fruit response to $1-\mathrm{MCP}$ treatment ${ }^{14,55}$. One common hypothesis is that the proportion of activated receptors bound to 1-MCP is affected by the IEC at the moment of treatment, since both compete for the receptor sites ${ }^{15}$. Moreover, it has been suggested that recovery from delayed 1-MCP treated apples is most likely due to synthesis of new receptors ${ }^{14}$, since 1-MCP appears to bind irreversibly in carnation tissue. Therefore, the second hypothesis we adopted was that in the delayed treated apples, the ETR expression (yielding $\mathrm{mRNA}_{\mathrm{ETR}}$ ) at the moment of treatment was so high that new receptors are rapidly regenerated, even if all receptors were blocked by 1-MCP. Finally, we postulated a third hypothesis in which the delayed treated fruit or late picked fruit were already at an advanced climacteric state before 1-MCP application, such that even if all receptors were blocked by 1$\mathrm{MCP}$, the fruit will rapidly produce more receptors due to the climacteric autocatalytic behaviour of ethylene at this stage. These three hypothesis were investigated using the model, by recalibrating the model, separately estimating treatment-specific values for the proportion of 
activated receptors bound to $1-\mathrm{MCP}, \chi_{\mathrm{ETR}_{\text {block }}}$, the ETR expression at treatment, $\mathrm{mRNA}_{\mathrm{ETR}, 0}$, or the initial climacteric state, $f_{\text {clim }, 0}$, respectively, while calculating the overall Root Mean Squared Error (RMSE) as a measure of how well the model described the data. All other model parameters were estimated together, except for the values of the ethylene production, the firmness and $a^{*}$-value at the start of shelf-life. The resulting RMSE's and the treatmentspecific model parameters are shown in Table 4. It should be noted that the model parameters in Table 3, with the associated model simulations plotted in Figure 3, were estimated with treatment-specific values for $\chi_{\text {(ETR-1-MCP) }}, \mathrm{mRNA}_{\mathrm{ETR}, 0}$, and $f_{\mathrm{clim}, 0}$. This was based on the initial assumptions that these parameters were responsible for the differences in ripening following the different treatments. However, in this second set of model calibrations, we aimed to investigate if any of these parameters was chiefly responsible for the different responses. For example, to investigate if the differences were due to differences in the climacteric state of the fruit at the moment of treatment, $\mathrm{mRNA}_{\mathrm{ETR}, 0}$ was set to a common value for all treatment, $\chi_{\mathrm{ETR}_{\text {block }}}$ was set at 0 for the control and 0.95 for all $1-\mathrm{MCP}$ treatments, while different values for $f_{\text {clim }, 0}$ were estimated for the optimally picked, delayed 1-MCP, and late picked apples. This procedure was repeated in an analogous way for $\chi_{\mathrm{ETR}_{\text {block }}}$ and $\mathrm{mRNA}_{\mathrm{ETR}, 0}$, while always keeping the other parameters at a common value.

It can be seen that the lowest RMSE were obtained when treatment-specific values were obtained either for $\chi_{\mathrm{ETR}_{\text {block }}}$ or $\mathrm{mRNA}_{\mathrm{ETR}, 0}$ (Table 4). This was also reflected in the poor model fit for both ethylene production and loss of green background colour, when treatment-specific values were estimated only for $f_{\text {clim }, 0}$ (Figure 4 ). This was particularly evident for the delayed 1-MCP treated fruit, meaning that differences in climacteric state of the fruit at the moment of treatment could not solely explain the rapid recovery from 1-MCP treatment in these fruit. Conversely, the differences in the proportion of receptors bound by 1-MCP or the expression 
level of the receptor genes at the moment of treatment could sufficiently account for the differences in response, as the model fit resulting from independently estimating treatmentspecific values for any of these two parameters were comparable to the model fit in Figure 3, in which treatment-specific values were estimated for all three parameters. However, by looking at the simulations in Figure 4 - treatment-specific $\mathrm{mRNA}_{\mathrm{ETR}, 0}$, the pattern of the evolution of the expression of the receptor genes is implausible, as one would normally expect a fast rise in receptor gene expression for the delayed 1-MCP treated fruit, as in Figure 2, rather than such high initial values. This suggests that the results in Figure 4- treatment-specific $\mathrm{mRNA}_{\mathrm{ETR}, 0}$ is a consequence of model overfitting. Therefore, while all three factors are likely to play some role in the poor response of delayed 1-MCP treated apples and 1-MCP treatment of late harvested apples, our model suggests that the poor response is most likely related to a low proportion of activated receptors bound to $1-\mathrm{MCP}$. Although ethylene receptors presumably have a much higher affinity for 1-MCP than ethylene, IEC may compete with 1-MCP for receptor sites ${ }^{15,56}$. In the delayed treated fruit, the IEC at the moment of 1-MCP application was most likely at levels sufficient to significantly compete with 1-MCP for the receptors. Our model supports the hypothesis that internal ethylene competes with 1-MCP, and is mainly responsible for poor 1MCP efficacy in apples that are treated following some delay after harvest or in apples that are harvested late. Jung and Watkins (2014) showed that there is a direct relation between 1-MCP efficacy and the IECs in apple fruit at the time of treatment. Based on the model fit with treatment-specific $\chi_{\mathrm{ETR}_{\text {block }}}$, a strong negative linear correlation was obtained between the estimated proportion of receptors bound by $1-\mathrm{MCP}$ and the ethylene emission at the moment of treatment, $\phi_{\mathrm{C}_{2} \mathrm{H}_{4}, 0}$ (Figure 5). Incomplete 1-MCP binding to receptor sites may also explain the partial response to 1-MCP observed in some apple cultivars, as cultivars with high IECs at harvest, such as 'McIntosh', often show only partial response to 1-MCP treatment ${ }^{17,57}$.

This article is protected by copyright. All rights reserved. 


\section{Predicting ripening of 1-MCP treated 'Jonagold' following storage at higher storage temperatures}

One of the advantages of 1-MCP treatment is that it could allow storage at more elevated temperatures, thereby reducing cost associated with electricity usage. However, it is important to be able to predict the fruit response during subsequent shelf life, following storage at such temperatures. The current model could assist in predicting the response of 'Jonagold' apples following 1-MCP treatment and storage at different temperatures. To validate the model, the evolution of ethylene production, firmness, and background colour during shelf life of optimally harvested 'Jonagold' apples treated with 1-MCP and stored for 6 months at $4{ }^{\circ} \mathrm{C}$ under $\mathrm{CA}$, were predicted using the model (Figure 6). Since 1-MCP treatment was done immediately after harvest, a 1-MCP blocking efficiency of 0.95 was assumed. The overall $\mathrm{R}^{2}$ of the validation dataset was more than $95 \%$. The predicted skin background colour was lower than the measured $a^{*}$ value, suggesting the temperature dependency of the rate constants for the reactions involving loss in skin greenness was not accurately defined. Nevertheless, the model provides a reasonable predictive tool for 1-MCP response of 'Jonagold' apples.

\section{Conclusions}

A kinetic model of 1-MCP regulation of ethylene production and quality degradation was developed. This is the first time such a model, capturing the dynamics of 1-MCP inhibition of ethylene perception and response, and climacteric ripening, has been developed. While the model does not account for the complete dynamic of the regulation of ethylene receptor proteins and details of the ethylene signal transduction pathway, given the current context, the state of the art of our knowledge and the richness of the current dataset, we consider the implemented level of model complexity to be well balanced. Using the model, different hypotheses for partial response of 'Jonagold' apples to 1-MCP treatment were investigated. A low proportion of activated receptors bound to $1-\mathrm{MCP}$, possibly resulting from competition with internal ethylene,

This article is protected by copyright. All rights reserved. 
is the main factor responsible for the observed partial response of 'Jonagold' apples to delayed 1-MCP treatment. The model also provides a valuable postharvest management tool for predicting ripening-related quality changes during shelf life exposure, following CA storage of 1-MCP treated 'Jonagold' apples. From a practical point of view, our model underlines the importance of a rapid application of 1-MCP after harvest to ensure optimal quality during shelflife following CA storage. The mechanistic basis of the model suggests the concept could be extended to different apple cultivars and other climacteric fruit.

\section{Acknowledgment}

This publication has been produced with the financial support of the European COST Action FA1106 ('QualityFruit'), the Research Council of the KU Leuven (OT 12/055, postdoctoral fellowship of author SGG) and the Flanders Fund for Scientific Research (project G.0603.08). The opinions expressed in this document do not by any means reflect the official opinion of the European Union or its representatives.

This article is protected by copyright. All rights reserved. 


\section{References}

1. Wu, Q., Szakacs-Dobozi, M., Hemmat, M. \& Hrazdina, G. Endopolygalacturonase in Apples (Malus domestica) and Its Expression during Fruit Ripening. Plant Physiol. 102, 219-225 (1993).

2. Gwanpua, S. G. et al. Pectin modifications and the role of pectin-degrading enzymes during postharvest softening of Jonagold apples. Food Chem. 158, 283-291 (2014).

3. Tateishi, A. et al. Differential expression and ethylene regulation of $\beta$-galactosidase genes and isozymes isolated from avocado (Persea americana Mill.) fruit. Postharvest Biol. Technol. 45, 56-65 (2007).

4. Gwanpua, S. G. et al. Expression analysis of candidate cell wall-related genes associated with changes in pectin biochemistry during postharvest apple softening. Postharvest Biol. Technol. 112, 176-185 (2016).

5. Purvis, A. C. \& Barmore, C. R. Involvement of ethylene in chlorophyll degradation in peel of citrus fruits. Plant Physiol. 68, 854-6 (1981).

6. Trebitsh, T., Goldschmidt, E. E. \& Riov, J. Ethylene induces de novo synthesis of chlorophyllase, a chlorophyll degrading enzyme, in Citrus fruit peel. Proc. Natl. Acad. Sci. U. S. A. 90, 9441-5 (1993).

7. Jacob-Wilk, D., Holland, D., Goldschmidt, E. E., Riov, J. \& Eyal, Y. Chlorophyll breakdown by chlorophyllase: isolation and functional expression of the Chlase 1 gene from ethylene-treated Citrus fruit and its regulation during development. Plant J. 20, 653-61 (1999).

8. Defilippi, B. G., Dandekar, A. M. \& Kader, A. A. Relationship of ethylene biosynthesis to volatile production, related enzymes, and precursor availability in apple peel and flesh tissues. J. Agric. Food Chem. 53, 3133-41 (2005).

This article is protected by copyright. All rights reserved. 
9. Flores, F. Role of ethylene in the biosynthetic pathway of aliphatic ester aroma volatiles in Charentais Cantaloupe melons. J. Exp. Bot. 53, 201-206 (2002).

10. Johnston, J. W., Gunaseelan, K., Pidakala, P., Wang, M. \& Schaffer, R. J. Co-ordination of early and late ripening events in apples is regulated through differential sensitivities to ethylene. J. Exp. Bot. 60, 2689-2699 (2009).

11. Stow, J. \& Genge, P. Low-ethylene storage of apples cv. 'Cox's Orange Pippin': effects of 'Rapid CA' and ultra-low oxygen. Ann. Appl. Biol. 117, 673-681 (1990).

12. Watkins, C. B. The use of 1-methylcyclopropene (1-MCP) on fruits and vegetables. Biotechnol. Adv. 24, 389-409 (2006).

13. Watkins, C. B. \& Nock, J. F. Rapid 1-methylcyclopropene (1-MCP) treatment and delayed controlled atmosphere storage of apples. Postharvest Biol. Technol. 69, 24-31 (2012).

14. Blankenship, S. M. \& Dole, J. M. 1-Methylcyclopropene: a review. Postharvest Biol. Technol. 28, 1-25 (2003).

15. Sisler, E. C. \& Serek, M. Inhibitors of ethylene responses in plants at the receptor level: Recent developments. Physiol. Plant. 100, 577-582 (1997).

16. Chiriboga, M.-A., Schotsmans, W. C., Larrigaudière, C., Dupille, E. \& Recasens, I. How to prevent ripening blockage in 1-MCP-treated 'Conference' pears. J. Sci. Food Agric. 91, 1781-1788 (2011).

17. Watkins, C. B., Nock, J. F. \& Whitaker, B. D. Responses of early, mid and late season apple cultivars to postharvest application of 1-methylcyclopropene (1-MCP) under air and controlled atmosphere storage conditions. Postharvest Biol. Technol. 19, 17-32 (2000).

18. Feng, X., Apelbaum, A., Sisler, E. C. \& Goren, R. Control of ethylene responses in avocado fruit with 1-methylcyclopropene. Postharvest Biol. Technol. 20, 143-150

This article is protected by copyright. All rights reserved. 
(2000).

19. Jiang, Y., Joyce, D. C. \& Macnish, A. J. Extension of the shelf life of banana fruit by 1methylcyclopropene in combination with polyethylene bags. Postharvest Biol. Technol. 16, 187-193 (1999).

20. Nock, J. F. \& Watkins, C. B. Repeated treatment of apple fruit with 1methylcyclopropene (1-MCP) prior to controlled atmosphere storage. Postharvest Biol. Technol. 79, 73-79 (2013).

21. Lu, X., Nock, J. F., Ma, Y., Liu, X. \& Watkins, C. B. Effects of repeated 1methylcyclopropene (1-MCP) treatments on ripening and superficial scald of 'Cortland' and 'Delicious' apples. Postharvest Biol. Technol. 78, 48-54 (2013).

22. Van de Poel, B., Bulens, I., Hertog, M. L. A. T. M., Nicolai, B. M. \& Geeraerd, A. H. A transcriptomics-based kinetic model for ethylene biosynthesis in tomato (Solanum lycopersicum) fruit: development, validation and exploration of novel regulatory mechanisms. New Phytol. 202, 952-63 (2014).

23. Van de Poel, B., Bulens, I., Hertog, M. L. A. T. M., Nicolai, B. M. \& Geeraerd, A. H. A transcriptomics-based kinetic model for ethylene biosynthesis in tomato (Solanum lycopersicum) fruit: development, validation and exploration of novel regulatory mechanisms. New Phytol. 202, 952-63 (2014).

24. Hertog, M. L. A. T. M., Nicholson, S. E. \& Jeffery, P. B. The effect of modified atmospheres on the rate of firmness change of 'Hayward' kiwifruit. Postharvest Biol. Technol. 31, 251-261 (2004).

25. Gwanpua, S. G. et al. Kinetic modeling of firmness breakdown in 'Braeburn' apples stored under different controlled atmosphere conditions. Postharvest Biol. Technol. 67, 68-74 (2012).

26. Johnston, J. W., Hewett, E. W., Hertog, M. L. A. T. . \& Roger Harker, F. Temperature

This article is protected by copyright. All rights reserved. 
induces differential softening responses in apple cultivars. Postharvest Biol. Technol. 23, 185-196 (2001).

27. Tijskens, L., Schouten, R. E., Konopacki, P. J., Hribar, J. \& Simčič, M. Modelling the biological variance of the yellow aspect of Granny Smith apple colour. J. Sci. Food Agric. 90, n/a-n/a (2010).

28. Nannyonga, S., Bakalis, S., Andrews, J., Mugampoza, E. \& Gkatzionis, K. Mathematical modelling of color, texture kinetics and sensory attributes characterisation of ripening bananas for waste critical point determination. J. Food Eng. 190, 205-210 (2016).

29. Van Dijk, C., Boeriu, C., Peter, F., Stolle-Smits, T. \& Tijskens, L. M. M. The firmness of stored tomatoes (cv. Tradiro). 1. Kinetic and near infrared models to describe firmness and moisture loss. J. Food Eng. 77, 575-584 (2006).

30. Ochoa-Ascencio, S., Hertog, M. L. A. T. M. \& Nicolaï, B. M. Modelling the transient effect of 1-MCP on 'Hass' avocado softening: A Mexican comparative study. Postharvest Biol. Technol. 51, 62-72 (2009).

31. Cocci, E., Sacchetti, G., Rocculi, P. \& Dalla Rosa, M. Response of Pink Lady ${ }^{\circledR}$ apples to post-harvest application of 1-methylcyclopropene as a function of applied dose, maturity at harvest, storage time and controlled atmosphere storage. J. Sci. Food Agric. 94, 26912698 (2014).

32. Yang, X., Song, J., Campbell-Palmer, L., Fillmore, S. \& Zhang, Z. Effect of ethylene and 1-MCP on expression of genes involved in ethylene biosynthesis and perception during ripening of apple fruit. Postharvest Biol. Technol. 78, 55-66 (2013).

33. Streif, J. in COST 94 (eds. de Jager A., Johnson, D. \& Hohn, E.) 15-20 (The postharvest treatment of fruit and vegetables: determination and prediction of optimum harvest date of apple and pears, 1996).

34. Bulens, I. et al. Protocol: An updated integrated methodology for analysis of metabolites

This article is protected by copyright. All rights reserved. 
and enzyme activities of ethylene biosynthesis. Plant Methods 7, 17 (2011).

35. O’Malley, R. C. et al. Ethylene-binding activity, gene expression levels, and receptor system output for ethylene receptor family members from Arabidopsis and tomato. Plant J. 41, 651-9 (2005).

36. Kamiyoshihara, Y., Tieman, D. M., Huber, D. J. \& Klee, H. J. Ligand-induced alterations in the phosphorylation state of ethylene receptors in tomato fruit. Plant Physiol. 160, 488-497 (2012).

37. Kieber, J. J., Rothenberg, M., Roman, G., Feldmann, K. A. \& Ecker, J. R. CTR1, a negative regulator of the ethylene response pathway in arabidopsis, encodes a member of the Raf family of protein kinases. Cell 72, 427-441 (1993).

38. Alonso, J. M., Hirayama, T., Roman, G., Nourizadeh, S. \& Ecker, J. R. EIN2, a bifunctional transducer of ethylene and stress responses in Arabidopsis. Science 284, 2148-52 (1999).

39. Kevany, B. M., Tieman, D. M., Taylor, M. G., Cin, V. D. \& Klee, H. J. Ethylene receptor degradation controls the timing of ripening in tomato fruit. Plant J. 51, 458-67 (2007).

40. Klee, H. J. \& Giovannoni, J. J. Genetics and Control of Tomato Fruit Ripening and Quality Attributes. Annu. Rev. Genet. 45, 41-59 (2011).

41. Alexander, L. \& Grierson, D. Ethylene biosynthesis and action in tomato: a model for climacteric fruit ripening. J. Exp. Bot. 53, 2039-2055 (2002).

42. Gwanpua, S. G. et al. Managing biological variation in skin background colour along the postharvest chain of 'Jonagold' apples. Postharvest Biol. Technol. 93, 61-71 (2014).

43. Brummell, D. A. Cell wall disassembly in ripening fruit. Functional Plant Biology 33, 103 (2006).

44. Fischer, M. Changes in the pectic substances of apples during development and 
postharvest ripening. Part 2: Analysis of the pectic fractions. Carbohydr. Polym. 25, $167-175$ (1994).

45. Vicente, A. R., Saladié, M., Rose, J. K. \& Labavitch, J. M. The linkage between cell wall metabolism and fruit softening: looking to the future. J. Sci. Food Agric. 87, 1435-1448 (2007).

46. Matile, P., Hortensteiner, S. \& Thomas, H. Chlorophyll degradation. Annu. Rev. Plant Physiol. Plant Mol. Biol. 50, 67-95 (1999).

47. Brummell, D. A. \& Harpster, M. H. Cell wall metabolism in fruit softening and quality and its manipulation in transgenic plants. Plant Mol. Biol. 47, 311-339 (2001).

48. Redgwell, R. J., Fischer, M., Kendal, E. \& MacRae, E. A. Galactose loss and fruit ripening: high-molecular-weight arabinogalactans in the pectic polysaccharides of fruit cell walls. Planta 203, 174-181 (1997).

49. Merzlyak, M. N. \& Solovchenko, A. E. Photostability of pigments in ripening apple fruit: a possible photoprotective role of carotenoids during plant senescence. Plant Sci. 163, $881-888$ (2002).

50. Gwanpua, S. G. et al. Towards flexible management of postharvest variation in fruit firmness of three apple cultivars. Postharvest Biol. Technol. 85, 18-29 (2013).

51. Hertog, M. L. A. T. M., Verlinden, B. E., Lammertyn, J. \& Nicolaï, B. M. OptiPa, an essential primer to develop models in the postharvest area. Comput. Electron. Agric. 57, 99-106 (2007).

52. Ambaw, A. et al. Modeling the diffusion-adsorption kinetics of 1-methylcyclopropene (1-MCP) in apple fruit and non-target materials in storage rooms. J. Food Eng. 102, $257-265$ (2011).

53. Watkins, C. B. \& Nock, J. F. Effects of delays between harvest and 1methylcyclopropene treatment, and temperature during treatment, on ripening of air-

This article is protected by copyright. All rights reserved. 
stored and controlled-atmosphere-stored apples. HortScience 40, 2096-2101 (2005).

54. Amarante, C. V. T. do, Argenta, L. C., Vieira, M. J. \& Steffens, C. A. Alteração da eficiência do 1-MCP com o retardo na sua aplicação após a colheita em maçãs ‘Fuji suprema'. Rev. Bras. Frutic. 32, 984-992 (2010).

55. Tatsuki, M., Endo, A. \& Ohkawa, H. Influence of time from harvest to 1-MCP treatment on apple fruit quality and expression of genes for ethylene biosynthesis enzymes and ethylene receptors. Postharvest Biol. Technol. 43, 28-35 (2007).

56. Serek, M., Sisler, E. C. \& Reid, M. S. Novel gaseous ethylene binding inhibitor prevents ethylene effects in potted flowering plants. J. Amer. Soc. Hort. Sci. 119, 1230-1233 (1994).

57. Jung, S.-K. \& Watkins, C. B. Internal ethylene concentrations in apple fruit at harvest affect persistence of inhibition of ethylene production after 1-methylcyclopropene treatment. Postharvest Biol. Technol. 96, 1-6 (2014).

This article is protected by copyright. All rights reserved. 
Table 1: Estimates, and associated standard deviation (S.D.), of model parameters of ethylene synthesis, perception, and signal transduction in 'Golden Delicious' apples. Parameters with no S.D were kept fixed during calibration.

\begin{tabular}{|c|c|}
\hline${ }^{\mathrm{a}}$ Parameter & Estimates (S.D.) \\
\hline$k_{\text {inact,ETR }}$ & $0.031(0.027)$ \\
\hline$k_{\mathrm{mRNA}_{\mathrm{ETR}}}$ & $14(5.0)$ \\
\hline$k_{\mathrm{deg}, \mathrm{mRNA}_{\mathrm{ETR}}}$ & 0.0001 \\
\hline$k_{t, \mathrm{ETR}}$ & 0.01 \\
\hline$k_{\mathrm{ERF}}$ & $13(5.4)$ \\
\hline$k_{\text {deg,ERF }}$ & 0.0001 \\
\hline $\mathrm{K}_{\mathrm{m}, \mathrm{ERF}}$ & 93 \\
\hline$\chi_{\mathrm{ETR}_{\text {block, 1-MCP }}}$ & 0.95 \\
\hline$\chi_{\mathrm{ETR}_{\text {block, control }}}$ & 0 \\
\hline$\left[\mathrm{mRNA}_{\mathrm{ETR}}\right]_{0}$ & $7.1(2.7)$ \\
\hline$\left[\mathrm{ETR}^{-}\right]_{0}$ & 1 \\
\hline$\left[\mathrm{ETR}^{+}\right]_{0}$ & 19 \\
\hline$[\mathrm{ERF}]_{0}$ & 1 \\
\hline$V_{\mathrm{m}, \mathrm{C}_{2} \mathrm{H}_{4} \text {, control }}$ & $23000(1200)$ \\
\hline$V_{\mathrm{m}, \mathrm{C}_{2} \mathrm{H}_{4}, 1-\mathrm{MCP}}$ & $17000(1700)$ \\
\hline$k_{\mathrm{clim}}$ & $0.59(0.11)$ \\
\hline$k_{\text {diff }}$ & 0.0065 \\
\hline$\phi_{\mathrm{C}_{2} \mathrm{H}_{4}, 0}$ & 0.0001 \\
\hline$f_{\text {clim }, 0}$ & 0.01 \\
\hline
\end{tabular}

${ }^{a}$ Rate constants for the inactivation of receptors, $k_{\text {inact,ETR }}\left(\mathrm{m}^{3} \mathrm{mmol}^{-1} \mathrm{~d}^{-1}\right)$, the expression of receptor genes, $k_{\text {mRNA }_{\text {ETR }}}\left(\mathrm{d}^{-1}\right)$, the degradation of receptor transcripts, $k_{\text {deg, } \text { mRNA }_{\text {ETR }}}\left(\mathrm{d}^{-1}\right)$, the

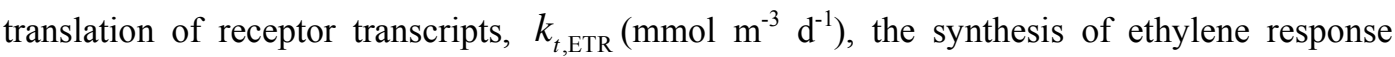

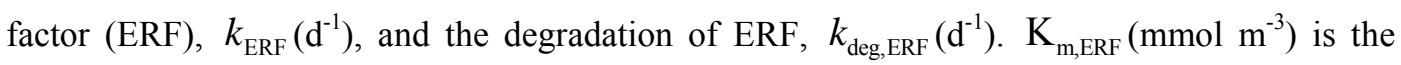
Michaelis-Menten constant for transition from pre-climacteric to climacteric, and $\chi_{\mathrm{ETR}_{\text {block }}}$ is the ratio of receptor blocked by $1-\mathrm{MCP} .\left[\mathrm{mRNA}_{\mathrm{ETR}}\right]_{0}$ is the mRNA abundance before controlled atmosphere (CA) storage, while $\left[\mathrm{ETR}^{-}\right]_{0}$ and $\left[\mathrm{ETR}^{+}\right]_{0}$ are the concentrations of the inactive and active receptors, respectively, before $\mathrm{CA}$ storage. $[\mathrm{ERF}]_{0}$ is the concentration of the ethylene response factor before $\mathrm{CA}$ storage. $V_{\mathrm{m}, \mathrm{C}_{2} \mathrm{H}_{4}}\left(\mathrm{mmol} \mathrm{m}^{-3} \mathrm{~d}^{-1}\right)$ is the rate constant for ethylene production, $k_{\text {clim }}\left(\mathrm{d}^{-1}\right)$ and $k_{\text {diff }}\left(\mathrm{d}^{-1}\right)$ are the rate constants for the change in climacteric state and ethylene diffusion from the fruit to the surrounding, respectively. $\phi_{\mathrm{C}_{2} \mathrm{H}_{4}, 0}\left(\mathrm{nmol} \mathrm{kg}^{-1} \mathrm{~s}^{-}\right.$ 
${ }^{1}$ ) and $f_{\text {clim, } 0}$ are the ethylene production and the climacteric state before CA storage. All rate constants are values at a reference temperature of $20^{\circ} \mathrm{C}$.

Table 2: Estimates of activation energies of different reactions in ethylene synthesis, perception, signal transduction, and response, as used in the model.

\begin{tabular}{|c|c|c|}
\hline${ }^{\mathrm{a}}$ Parameter & ${ }^{b}$ Estimates $\left(\mathrm{J} \mathrm{mol}^{-1}\right)$ & Source \\
\hline $\mathrm{Ea}_{\mathrm{ETR}, \text { inact }}$ & 43000 & - \\
\hline $\mathrm{Ea}_{\mathrm{ETR}, \mathrm{deg}}$ & 112000 & - \\
\hline $\mathrm{Ea}_{\mathrm{ETR}, t}$ & 82000 & - \\
\hline $\mathrm{Ea}_{\mathrm{mRNA}_{\mathrm{ETR}}}$ & 40000 & - \\
\hline $\mathrm{Ea}_{\mathrm{mRNA}_{\mathrm{ETR}}, \mathrm{deg}}$ & 76000 & - \\
\hline $\mathrm{Ea}_{\mathrm{ERF}}$ & 101000 & - \\
\hline $\mathrm{Ea}_{\mathrm{ERF}, \mathrm{deg}}$ & 120000 & - \\
\hline $\mathrm{Ea}_{\mathrm{Chl}}$ & 150000 & Gwanpua et al. ${ }^{55}$ \\
\hline $\mathrm{Ea}_{\mathrm{E}_{\text {Chlase }}}$ & 100000 & Gwanpua et al. ${ }^{55}$ \\
\hline $\mathrm{Ea}_{\mathrm{E}_{\text {Chlase,deg }}}$ & 80000 & Gwanpua et al. ${ }^{55}$ \\
\hline $\mathrm{Ea}_{\text {Pect }}$ & 90000 & Gwanpua et al. $^{47}$ \\
\hline $\mathrm{Ea}_{\mathrm{E}_{\text {Pect }}}$ & 60000 & Gwanpua et al. ${ }^{47}$ \\
\hline $\mathrm{Ea}_{\mathrm{E}_{\text {Pect,deg }}}$ & 65000 & Gwanpua et al. $^{47}$ \\
\hline $\mathrm{Ea}_{\text {clim }}$ & 75000 & - \\
\hline $\mathrm{Ea}_{\mathrm{Vmax}_{\mathrm{C}_{2} \mathrm{H}_{4}}}$ & 71400 & Gwanpua et al. $^{47}$ \\
\hline
\end{tabular}

${ }^{a}$ Activation energies of inactivation of receptors $\left(\mathrm{Ea}_{\mathrm{ETR} \text {,inact }}\right)$, degradation of receptors ( $\left.\mathrm{Ea}_{\mathrm{ETR}, \text { deg }}\right)$, translation of receptor transcripts $\left(\mathrm{Ea}_{\mathrm{ETR}, t}\right)$, expression of receptor genes ( $\left.\mathrm{Ea}_{\text {mRNA }_{\mathrm{ETR}}}\right)$, degradation of receptor transcripts $\left(\mathrm{Ea}_{\mathrm{mRNA}_{\mathrm{ETR}}, \mathrm{deg}}\right)$, production of ethylene response factor $\left(\mathrm{Ea}_{\mathrm{ERF}}\right)$, degradation of ethylene response factor $\left(\mathrm{Ea}_{\mathrm{ERF}, \mathrm{deg}}\right)$, degradation of skin chlorophyll pigments $\left(\mathrm{Ea}_{\mathrm{Chl}}\right)$, synthesis of chlorophyllase $\left(\mathrm{Ea}_{\mathrm{E}_{\text {Chlase }}}\right)$, degradation of chlorophyllase $\left(\mathrm{Ea}_{\mathrm{E}_{\text {Chlasedeg }}}\right)$, degradation of cell wall pectin $\left(\mathrm{Ea}_{\text {Pect }}\right)$, synthesis of pectinases ( $\left.\mathrm{Ea}_{\mathrm{E}_{\text {Pect }}}\right)$, degradation of pectinase $\left(\mathrm{Ea}_{\mathrm{E}_{\text {Pect,deg }}}\right)$, transition from pre-climacteric to climacteric ( $\left.\mathrm{Ea}_{\text {clim }}\right)$, and ethylene biosynthesis $\left(\mathrm{Ea}_{\mathrm{Vmax}_{\mathrm{C}_{2} \mathrm{H}_{4}}}\right)$.

This article is protected by copyright. All rights reserved. 
Table 3: Model parameter estimates, and the standard deviations (S.D), of the model for ethylene response in 'Jonagold' apples (Eqs. (1) - (13)). Parameters with no S.D were kept fixed.

\begin{tabular}{l|l}
\hline Common parameters & Value (S.D.) \\
\hline$k_{\text {Pect }}$ & $0.000043(0.000004)$ \\
$k_{\mathrm{E}_{\text {Pect }}}$ & 0.59 \\
$F_{\mathrm{c}}$ & 38 \\
$k_{\mathrm{Chl}}$ & $0.0014(0.0003)$ \\
$k_{\mathrm{E}_{\mathrm{Chl}}}$ & 0.36 \\
$a_{\mathrm{c}}^{*}$ & $6.6(1.0)$ \\
$k_{\mathrm{clim}}$ & $1.3(0.08)$ \\
\hline
\end{tabular}

\begin{tabular}{l|l|l|l|l}
\hline $\begin{array}{l}\text { Treatment- } \\
\text { specific } \\
\text { parameters }\end{array}$ & \multicolumn{5}{|c}{ Value (S.D.) } \\
\cline { 2 - 5 } & Control & 1-MCP & $\begin{array}{l}\text { Delayed 1- } \\
\text { MCP }\end{array}$ & 1-MCP late picked \\
\hline $\mathrm{F}_{0}$ & $74(1)$ & $74(1)$ & $68(2)$ & $72(1.9)$ \\
$a_{0}^{*}$ & $6.1(0.6)$ & $6.1(0.6)$ & $6.3(1.0)$ & $4.1(0.8)$ \\
$\phi_{\mathrm{C}_{2} \mathrm{H}_{4}, 0}$ & $0.0005(0.0003)$ & $0.0005(0.0003)$ & $0.0018(0.028)$ & $0.00016(0.0018)$ \\
$V_{\mathrm{m}_{2} \mathrm{H}_{4}}$ & $27400(2000)$ & $15400(1000)$ & $15400(1000)$ & $15400(1000)$ \\
$f_{\text {clim,0 }}$ & 0.01 & 0.01 & $0.016(0.018)$ & $0.0090(0.0087)$ \\
$\chi_{\mathrm{ETR}_{\text {block }}}$ & 0 & 0.95 & $0.42(0.46)$ & $0.99(0.32)$ \\
{$\left[\mathrm{mRNA}_{\mathrm{ETR}}\right]_{0}$} & 7.1 & 7.1 & $7.8(11.3)$ & $12(22)$ \\
\hline
\end{tabular}

${ }^{\mathrm{a}} k_{\text {Pect }}\left(\mathrm{mol}^{-1} \mathrm{~m}^{3} \mathrm{~d}^{-1}\right)$, is the rate constant for pectin degradation; $k_{\mathrm{E}_{\text {Pect }}}\left(\mathrm{d}^{-1}\right)$ is the rate constant for the synthesis of pectinases; $k_{\mathrm{Chl}}\left(\mathrm{mol}^{-1} \mathrm{~m}^{3} \mathrm{~d}^{-1}\right)$, is the rate constant for breakdown of chlorophyll; $k_{\mathrm{E}_{\mathrm{Chl}}}\left(\mathrm{d}^{-1}\right)$ is the rate constant for synthesis of chlorophyllase; $F_{\mathrm{c}}(\mathrm{N})$ is the fixed part of firmness not affected by pectin breakdown; $\mathrm{F}_{0}(\mathrm{~N})$ and $a_{0}^{*}$ are the firmness and $\mathrm{a}^{*}$-value just before controlled atmosphere $(\mathrm{CA})$ storage, respectively; $\mathrm{E}_{\mathrm{Pect}, 0}$ and $\mathrm{E}_{\mathrm{Chl}, 0}$ are the amount of pectinases and chlorophyllase present in the fruit just before CA storage, respectively; $a_{\mathrm{c}}^{*}$ is related to a fixed part of skin colour pigment, not influenced by chlorophyll degradation.

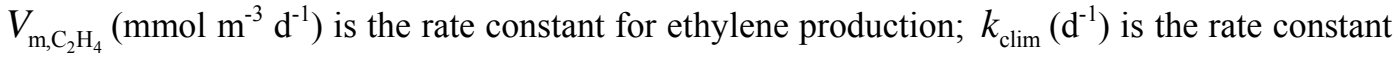
for the change in climacteric state; $\left[\mathrm{mRNA}_{\mathrm{ETR}}\right]_{0}, \phi_{\mathrm{C}_{2} \mathrm{H}_{4}, 0}\left(\mathrm{nmol} \mathrm{kg}^{-1} \mathrm{~s}^{-1}\right), f_{\text {clim, }, 0}$ and are the receptor genes expression, the ethylene production, and the climacteric state just before CA storage, respectively, and $\chi_{\mathrm{ETR}_{\text {block }}}$ is the ratio of ETR receptors bound by 1-MCP before CA storage.

This article is protected by copyright. All rights reserved. 
Table 4: Experiment-specific model parameters for the initial climacteric state, $f_{\text {clim }, 0}, 1-\mathrm{MCP}$ blocking efficacy, $\chi_{\mathrm{ETR}_{\text {block }}}$, and initial mRNA abundance of the receptor genes. The model parameter values were estimated by refitting the data to the model to obtain treatment-specific values for one of these three parameters, and keeping the other model parameters common for all treatments. The model fit was calculated in terms of the overall Root Mean Square Error (RMSE).

\begin{tabular}{llll}
\hline Model fit & RMSE & Treatment & Estimates (S.D) \\
\hline Treatment-specific $\left[\mathrm{mRNA}_{\mathrm{ETR}}\right]_{0}$ & 0.43 & Control & 7.1 (fixed) \\
& & 1-MCP & 7.1 (fixed) \\
& & Delayed 1-MCP & $24(30)$ \\
& & 1-MCP late picked & $14(19)$ \\
\hline Treatment-specific $\chi_{\text {ETR }_{\text {block }}}$ & 0.38 & Control & 0 (fixed) \\
& & 1-MCP & 0.95 (fixed) \\
& & Delayed 1-MCP & $0.38(0.43)$ \\
Treatment-specific $f_{\text {clim,0 }}$ & \multirow{2}{*}{0.61} & 1-MCP late picked & $0.69(0.09)$ \\
& & Control & 0.01 (fixed) \\
& & 1-MCP & 0.01 (fixed) \\
& & Delayed 1-MCP & $0.20(0.08)$ \\
& & 1-MCP late picked & $0.06(0.04)$ \\
\hline
\end{tabular}

This article is protected by copyright. All rights reserved. 

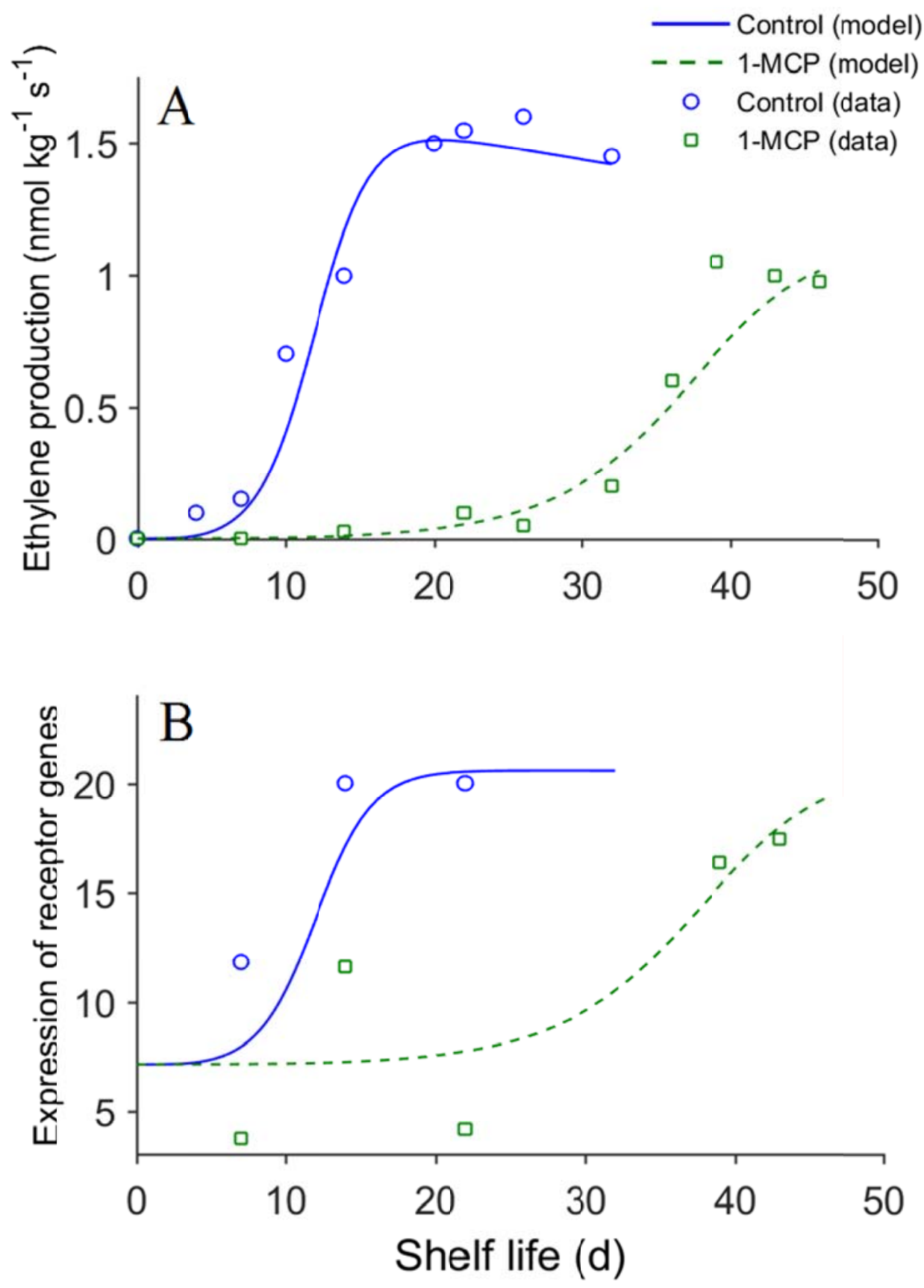

Figure 2: The evolution of ethylene production (A) and expression of ethylene receptor genes (B) of 1-MCP treated and control 'Golden Delicious' apples during ripening at $20^{\circ} \mathrm{C}$. The lines are the model predictions, while the points are measurement data.

This article is protected by copyright. All rights reserved. 

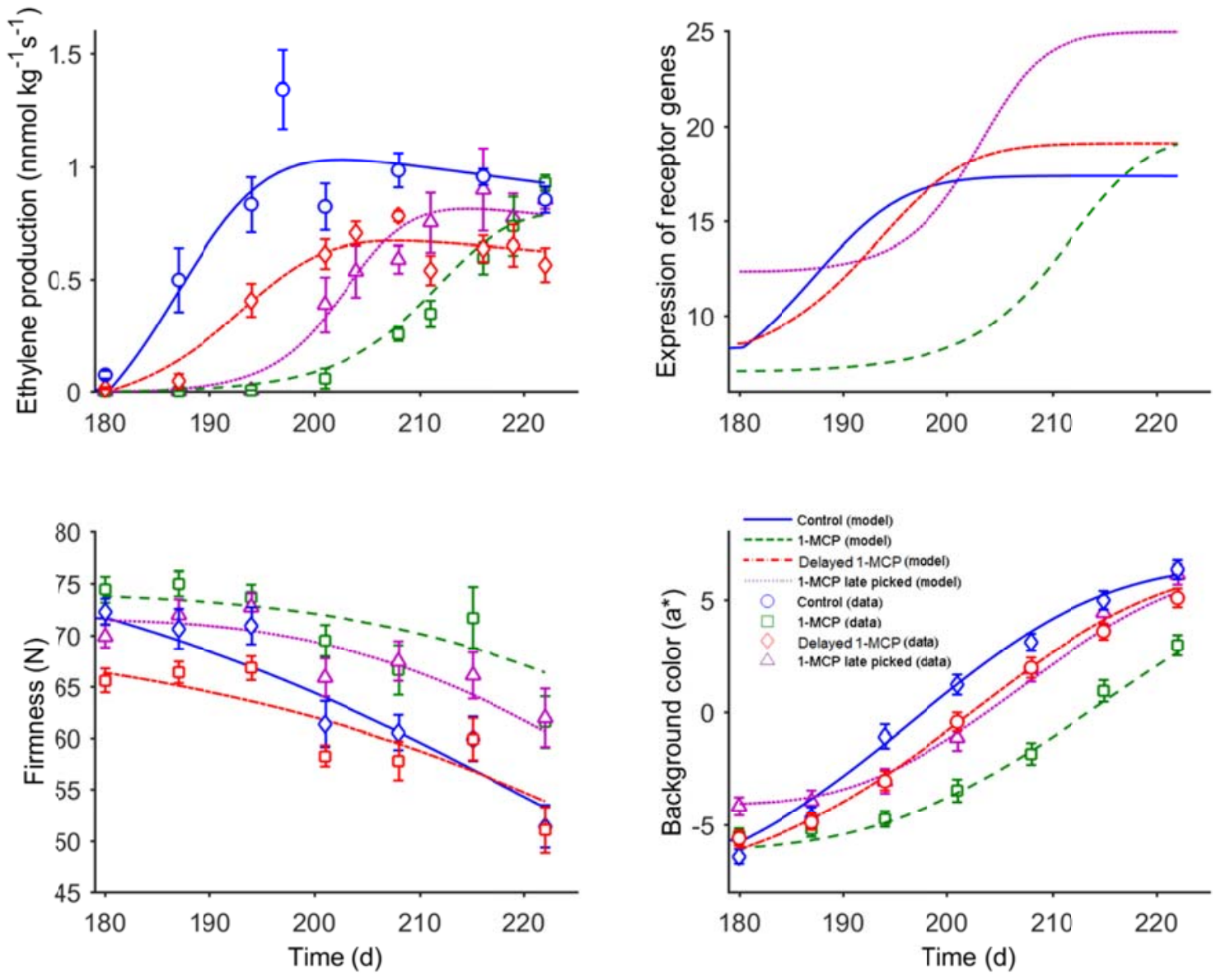

Figure 3: The evolution of ethylene production (A), expression of ethylene receptor genes (B), firmness (C), and skin background colour ( $a^{*}$-value) (D) during shelf life $\left(18^{\circ} \mathrm{C}\right.$ under air) exposure of 1-MCP treated and control 'Jonagold' apples, following $180 \mathrm{~d}$ storage.

This article is protected by copyright. All rights reserved. 


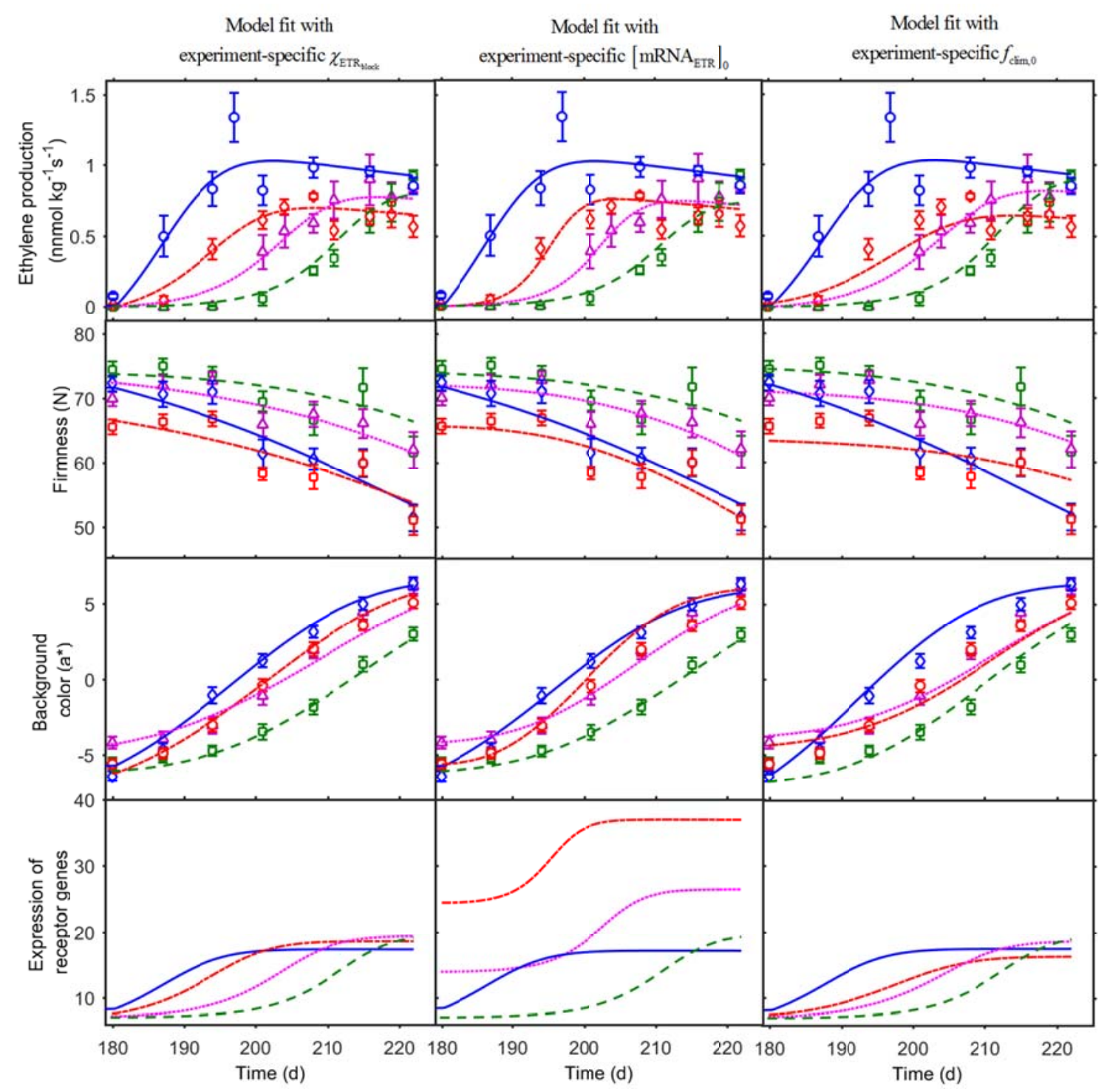

Figure 4: Model predictions plotted against measurements for three different model fit.

This article is protected by copyright. All rights reserved. 


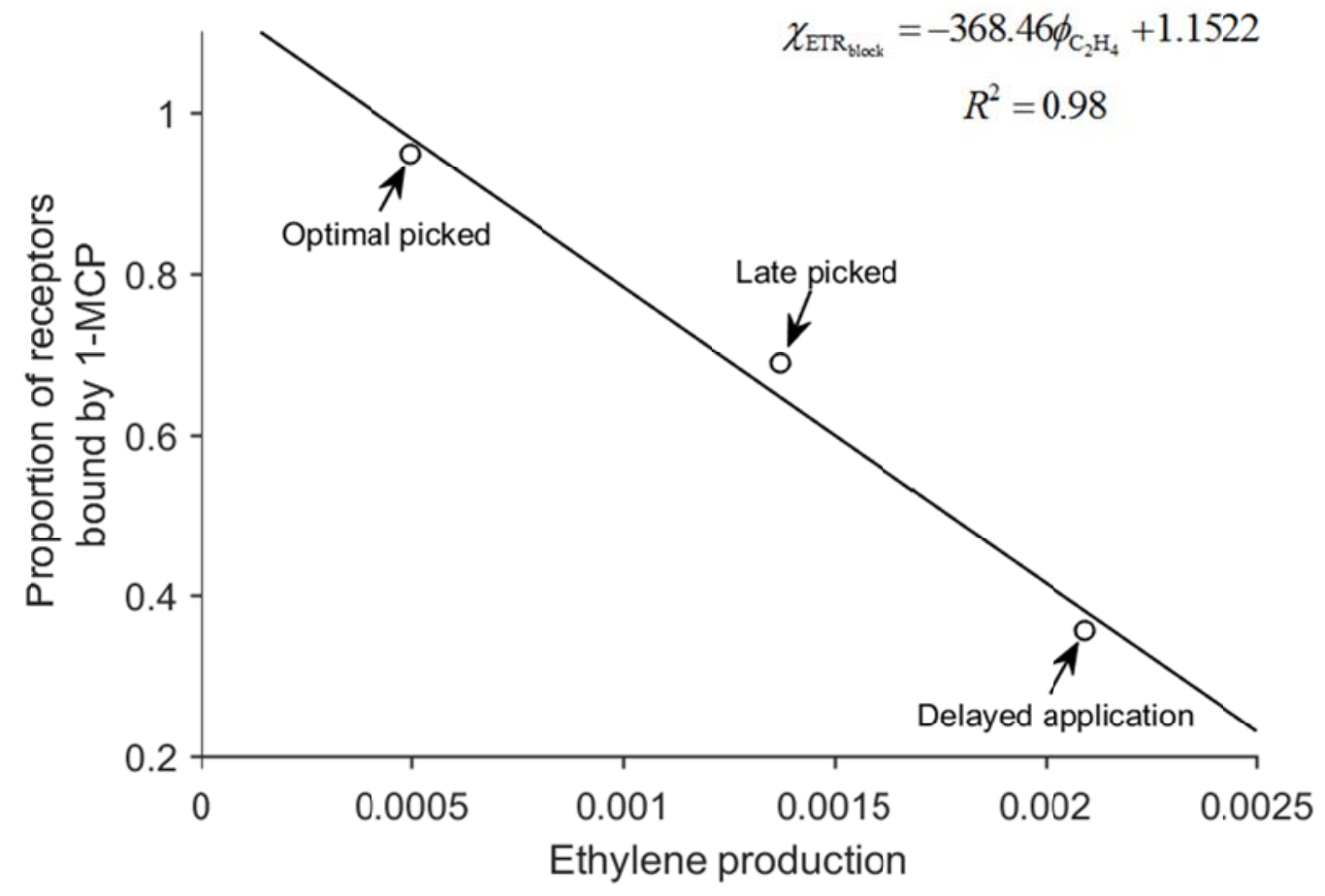

Figure 5: Relationship between the predicted proportion of ethylene receptors bound by 1MCP, $\chi_{\text {ETR }_{\text {block }}}$, and the ethylene production at the moment of treatment, $\phi_{\mathrm{C}_{2} \mathrm{H}_{4}, 0}$, based on model fit with treatment-specific $\chi_{\mathrm{ETR}_{\text {block }}}$.

This article is protected by copyright. All rights reserved. 

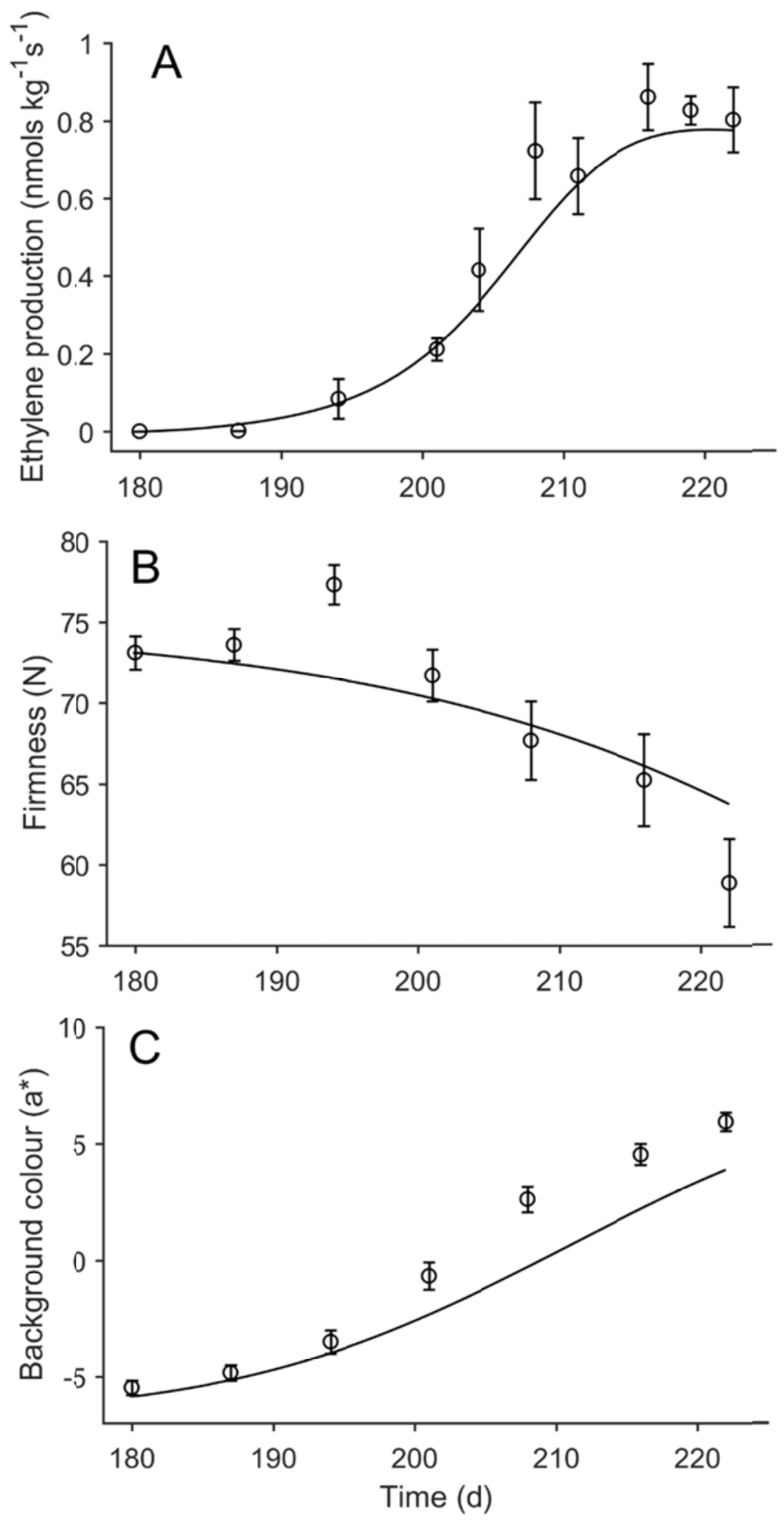

This article is protected by copyright. All rights reserved. 
Figure 6: Prediction of the evolution of ethylene production, firmness, and background colour of 1-MCP treated 'Jonagold' apples during ripening at shelf life conditions $\left(18{ }^{\circ} \mathrm{C}\right.$, under regular air), following storage at $4{ }^{\circ} \mathrm{C}$ under controlled atmosphere.

This article is protected by copyright. All rights reserved. 